\title{
Role of Gender Diversity in Corporate Risk Taking in Jordan
}

\author{
Dr. FERAS IZZAT OQLAH KASASBEH \\ Assistant Professor, Administrative Sciences Dept. \\ Community College - University of Tabuk - KSA \\ E-Mail: $\underline{\text { fkasasbeh@ut.edu.sa }}$
}

\begin{abstract}
This study examines the relationship between board gender diversity and corporate risk-taking among Jordanian companies. Pooled Ordinary Least Square (OLS) regression and Panel Data regression are used in this study to examine the relationship between these variables. Results indicate that the presence of women directors can mitigate corporate risk-taking a while; male-only board leads to higher level of firm risk-taking. This study concludes that board gender diversity can be used as a monitoring agent to mitigate corporate risk-taking, supporting the regulator's initiative to promote gender diversity in the corporate boardrooms.
\end{abstract}

Keywords: Board gender Diversity, Corporate Risk-taking.

\section{Introduction}

Corporate risk-taking has great influence on firms performance (John, Litov, and Yeung, 2008) and is very important. The firms' risk-taking behaviors can affect firms' performance significantly. The growth of firms and shareholders' value could be benefitted from growth-oriented corporate risk-taking. A certain level of risk to create economic value is in fact needed by firms, but adverse effects can be caused by excessive risk-taking. Mismanagement of risk exposures and excessive risk-taking are the reasons that lead to the collapse of Lehman Brothers (Waring, 2013) and financial crises in 2008.

As a part of business development, corporate risk-taking is dealt with uncertainty. The key responsibility of the board is the effectiveness of corporate risk-taking. The risk-taking is evaluated by the, where the board is assumed to recognize the possible outcomes and make a decision on risk-taking because excessive risktaking could lead to adverse results that impact firm performance negatively. Therefore, for the firms' sustainability corporate risk-taking is very crucial.

Being a part of the governance structure of a firm, the board of governors is important in decision-making process (Fama and Jensen 1983). Decisions about the firm's investment choices are included in decisionmaking. Crucial for the firm in order to gain profit from the choices are investment decisions. Moreover, to lead the companies in achieving the firms' objectives and to protect the shareholder's wealth is the responsibility of the board of governors. Therefore, the board becomes a key mechanism (Xie, Davidson, and DaDalt, 2003; Javed, 2018; De Andres and Vallelado, 2008) that monitor the management, protect the shareholder's interest and the management on the strategy identification and implementation advises. The board as the firms' front-liners has to ensure that the firm conducts in compliance with the ethical values and laws. In order to ensure the right management of risk and level of internal control board must also maintain the effectiveness of the governance structure. 
Board gender diversity has become an issue receiving considerable attention within the issues of corporate governance in recent years. Incorporate decision making female representative has become a significant consideration for policymakers. In all public firms in Norway, it's mandatory to fulfil the $40 \%$ gender quota for female directors and it had been achieved in full compliance in 2008 as announced by the government. Spain introduced a law requiring the firms to increase the share of female directors to $40 \%$ by 2015 (Adams and Ferreira, 2009) following Norway in the same regard. while companies are required to voluntarily reserve a minimum of $25 \%$ quota for female directors in Sweden. For all public companies in Netherland, the target female quota on corporate boards is set at 30\%. Companies have to explain the non-compliance in the annual reports and the steps to be taken to achieve the target (Catalyst, 2013) if the target remained unachieved. India, Japan, Australia, Singapore and other countries around the world have also started to consider the issue of board gender diversity.

Board independence, board size, CEO duality and board gender diversity are some of the characteristics that are highlighted in the literature. To formalize its approach to boardroom diversity board should establish a policy. To ensure that women candidates are sought as part of its requirement exercise board should step through its Nominating committee. In the annual reports, its gender diversity policies and targets, as well as the measures to be taken to meet those targets, should be clearly stated by the board.

To improve the quality of board discussion and the ability of the board to provide effective oversight of the firm's disclosure and reports (Gul, Srinidhi, and Ng, 2011) board gender diversity is argued. Gender diversity in the boardrooms can also create a better understanding of the business environment that can improve the decision-making process of the firm. The creativity and innovation of product and services of firms (Campbell and Minguez-Vera, 2007) can be enhanced by the difference in the male and female behaviours and risk attitudes. As they place more concern on the market, environment and ethical issues than male counterpart (Bilimoria, 2000), female directors are found to be better in firm monitoring (Adams and Ferreira, 2009). According to Charness and Gneezy (2012), women are more risk-averse and thus are likely to take less risk than men (Dwyer, Gilkeson, and List, 2002). The effectiveness of firm's decisionmaking process can be decreased, as the process will take a longer time to come to a decision, various perspectives being heard and considered in the boardrooms (Rose, 2007) because of board gender diversity.

Multiple types of risk such as the sub-prime mortgage, merger and acquisition, treasury risk, credit risk, security, marketing, capital project and many more are faced by firms. The firm's operation can get the impact of any type of risk. The relationship between board gender diversity and corporate risk-taking among Jordanian public listed companies would be examined in the current study. Regulators and firms pay more attention to improve corporate governance to strengthen public confidence post-2008 financial crises.

In the context of Jordan, the issue of board gender diversity and corporate risk-taking are relatively unexplored. In Jordan, most studies on board gender diversity, firm performance is focused. Low et al. (2015), for example, found that increasing number of female directors on the board have a positive impact on the Asian firm performance, like Hong Kong, South Korea, Malaysia, and Singapore. On the other hand, Siti Norwahida et al. (2012) found that the public firm performance is not affected by board gender diversity. The direct relationship between board gender diversity and performance is examined in aforementioned studies and how board gender diversity would affect firms' decision in relation to corporate risk-taking behaviour that would ultimately affect firms' performance is not considered. Therefore, there is a need to go one step in depth to examine the relationship between board gender diversity and firms risktaking behaviour.

Jordanian firms are mostly dominated by male directors on board as being a developing country. The low ratio of female directors in the boardrooms shows clearly. The ratio of female board members of Jordanian public listed firms is still far behind the targeted 30\% quota indicating that Jordanian firms are still doubtful about board gender diversity benefits to their firms. Powell and Ansic, (1997) stated that women are argued 
to be more cautious, less aggressive and easier to persuade than men and tend to be associated with less risk-taking as compared to men. As compared to men CEOs (Faccio, Marchica and Mura, 2016) firms run by female CEOs have lower gearing ratio, less volatile earnings, and are expected to stay longer in operation.

Men as studies found, tend to favour risky investment (see example Dwyer, et al. 2002; Charness and Gneezy, 2012; Eckel and Grossman, 2008; Croson and Gneezy, 2009) while women found to be riskaverse and take fewer risks in investment. Contrary to this, female fund managers hold portfolios with slightly higher risk than the male counterpart as showed by Potter (2002). Despite the importance of the issue on board gender diversity and corporate risk-taking, The question "How board gender diversity would affect firms' risk-taking behaviour?" has not been answered despite the importance of board gender diversity in corporate risk-taking, specifically in the Jordanian context, where there are fewer incentives to increase female participation in the boardrooms in majority of the public listed firms.

\section{Theoretical Review}

Participation and proportion of female directors on boards would affect corporate risk-taking behaviour or not, this issue on board gender diversity has been getting more attention in recent years. No specific theory is directly related to the topic of board gender diversity and corporate risk-taking, therefore, this study refers to the theories which are closely related to the research objectives like resource dependence theory, agency theory and behavioural theory.

\section{Behavioral Theory}

According to Cyert and March, (1963) behavioral theory is more related to the board gender diversity. The differences in risk-taking behaviors that would affect firms' decision-making process may be affected by the differences in attitudes of genders. Individual risk-taking preferences are likely to depend on the differences in the behavior between men and women according to various scholars in psychology and finance. Psychologies in this area find that Men are more overconfident than women, instead, women are found to be emotional than men finds the psychologies in this area.

Men and women have a different emotional reaction to uncertainty and men are overconfident than women where it may affect the possible outcomes as documented by Croson and sneezy (2009). Women in boards contribute to a better quality of the decision-making process (N. Smith, V.Smith and Verner, 2006). As women tend to be more cautious in making a decision (Powel and Ansic, 1997), therefore decision making process would take more time (Berger, Kick and Schaeck, 2012; A. A. Khan \& Javed, 2017).

Risk preferences as it is expected are related to gender differences. Women are more sensitive to losses; therefore, they tend to be less risk-taking than men (see example Croson and Gneezy, 2009; Powel and Ansic, 1997) that is risk-averse.

\section{Resource dependence theory}

How external resources affect organizational behaviour comes under the resource dependence theory. Pfeffer and Salancik (1978) stated, to bring resources to the firm and to connect the firm with the external environment is the role of the board as defined by the theory. A firm can make a link with the elements of its external environment to obtain resources Pfeffer and Salancik presented the idea and board of directors is the main linkage mechanism that connects a firm with the sources of external dependency. By having a board of directors with skills, influences and connection to the external dependency (Hillman Shropshire Cannella, 2007), a firm can obtain the resources and reduce dependency. (Prefer and Salancik (1978) and A. Khan \& Javed, 2016) 
Highlight four benefits that a board of directors can bring to a firm, including advice and counsel, the channel of information flow, preferential access to resources, and legitimacy is highlighted by Pfeffer and Salancik (1978). Moreover other than that, Pfeffer and Salancik (1978) state that the environmental dependencies could be managed by the board and environmental needs would be reflected by the board of directors as well.

The dependence of important resources would influence the actions of an organization, is the underlying assumption of the resource dependence theory. On the particular dependency situation, in addition, the organization actions and decisions can be explained. The environment is supposed to contain uncommon and valued resources crucial to an organization exists, is another assumption. Briefly, this Theory identifies the influence of external factors on organisational behaviour. The optimal divisional structure of the organisation and contract structure of external organizational links are the implications of resource dependence theory as well as other aspects of organizational strategies other implications include the production of strategies, recruitment of board of directors and employees.

\section{Agency Theory}

Agency theory is another theory that is related to this study is by Jensen and Meckling (1976). The interests between managers and owners are different due to the separation of ownership and control in business argues agency theory. The problem of risk sharing could arise because of the differences in risk preference between the agent and principle stated Eisenhardt (1989). When the agents take a different action than the principles, this problem can lead to agency cost. Board of directors is an important internal governance instrument to prevent managers to act on their self-interest at the expense of profit maximization and thus creating agency cost states agency theory.

Between the shareholders and managers, agency cost of equity is about the conflict of interest because these two parties have different interests. Where the shareholders' objective is to maximize their wealth while on the other hand, the managers' objectives are to expand the company operation for others' benefit, to increase company's value and to make sure company' objectives are achieved. Over-investment can be the cause of agency cost of equity. Where the managers would invest in many projects including risky investments with negative net present value, the over-investment problem occurs. Managers may also have personal goals, which may not be the interest to increase the share value.

\section{Empirical Review}

Limited studies have been done on board gender diversity and corporate risk-taking. This subsection reviews the empirical studies from two individual perspectives that are the corporate risk-taking and board gender diversity.

\section{Corporate Risk Taking}

The relationship between CEO gender and corporate risk-taking in Europeans was investigated by Faccio, et al (2016). A large sample firm from public-held and public-traded European firms was used in their study. The CEO gender determines the corporate decision making was the finding of the study. Women tend to be associated with less risky firms. It was also found that firms run by female CEO are less levered, less volatile, and are expected to stay longer in operations (Faccio et al 2016) in comparison to firms managed by male CEO.

How age, gender and education affect the risk-taking behaviour among banks in Germany for the period starting from 1994 until 2010 was examined by Berger et al (2012). The decrease in the average age of the board increases banks risk taking because different age has different attitudes towards risk, the result of difference-in-difference estimation revealed. For the gender, the result shows that As the proportion of 
women in boards increases bank risk-taking also increases even though this effect is not significant as result for gender showed. Female directors are less experienced than male was documented by Berger et al (2012). Negative results with regard to education were found, suggesting that more educated board results in lower risk-taking because better risk management techniques and adjust the business model accordingly would be applied by the better-educated board.

It was found by Nguyen (2011) that risk-taking is associated with corporate governance structures. The influences of corporate governance on risk-taking among Japanese firms is examined in the paper. The firms with family control and concentrated ownership are related to higher firm-specific risk was revealed by the result. To strengthen firms' competitive position, family-owned firms adopt distinctive strategies that are more risky to contribute. Banks being unfavourable to the firm competitive position, therefore, bank-controlled firms are related to lower firm-specific risk.

The impact of shareholders' identity on corporate risk-taking among 190 newly privatized firms from 39 countries was investigated by Boubakri, Cosset and Saffar (2013). The state ownership is negatively related to corporate risk-taking, result while foreign ownership is positively related to the corporate risk-taking result shows. However, the foreign owners' high risk-taking preferences depend on the country-level governance institution (Boubakri et al. 2013a) while, firm-level corporate risk taking depends on countrylevel governance institution (see example John, et al. 2008).

The effect of the political institution on the corporate risk-taking is examined by Boubakri, Mansi and Saffar (2013b). The political connection is positively related to corporate risk-taking is the finding of the study. A large sample of non-financial firms from 77 countries starting the year 1988 until 2008 is utilized in the study. Because the close ties with the government lead the firms to less conservative investment choices, therefore, firms with political connection have higher volatile earnings. If the firm falls into financial distress (Faccio, Masulis and McConnel, 2006)with political link more possible to be bailed out by the government.

$\mathrm{Ng}$, Chong and Ismail (2013) examine the effect of firm size on the firm risk-taking behaviour among Malaysian insurance firms during the period of 2000 until 2010 for the developing countries. The results reveal that because of the certainty of possible bailed out by government underwriting risk is positively related to the insurance firm size. In other words, large size insurance firms are likely to take more risk.

\section{Board Gender Diversity}

Firm performance is mainly focused on existing studies on boards' gender diversity. Gender diversity leads to better firm performance (Carter, Simkins and Simpson, 2003; Campbell and Minguez-Vera 2008) finds the study. Firms with gender diverse board have better creativities and innovations suggest Robinson and Dechant (1997) because of the knowledge and experiences contributed by the gender diversified board and the difference of skills. Tu, Loi, and Yen (2015) investigate the relationship between gender diversity of board and bank performance using a sample of ASEAN banks from Vietnam, Indonesia and Thailand. The gender diversity and firm performance are positively related in the result of the study. Likewise, Campbell and Mínguez-Vera (2008) also find board diversity to be positively related to firm performance. In Spain, this relationship is examined using listed firms. Given the better understanding of business environment (Campbell and Minguez-Vera 2008), the diversity on board

The female directors have a better understanding in particular market condition than male this is one of the advantages stated by N. Smith, et al (2006). Moreover, the presence of more women directors may generate a better public image of the firm and contribute to decision making and the improvement of firm performance. An increasing number of female directors on the board have a positive impact on the firm performance is also find by Low, et al (2006) in a sample of Asian firms from Singapore, Hong Kong, South Korea and Malaysia. Low et al. (2015) also find that due to tokenism and cultural resistance the 
benefits of female directors decrease in countries with higher female economic participation and empowerment.

Using a sample of major US-based corporation listed in S\&P 500, Carter, D'Souza, Simkins and Simpson (2010) find that financial performance is not affected by gender and ethnic diversity. Different laws, cultural environment, geography, and other factors that may affect board diversity on board performance can be the reason. The presence of female directors in the boardrooms does not affect Danish firms performances, is find by Rose (2007) because the female board members are not from the 'old boys club'. Therefore, females have to try to adapt to the traditional way.

Gul, et al. (2011) states that board diversity could improve the quality of public disclosure through good monitoring while Adams and Ferreira, (2009), find the negative relationship between gender diversity and firm performance. The firms that already have strong corporate governance; the presence of women on the board may lead to over monitoring. Women being more active in monitoring activities in contrast to male directors (Adams and Ferreira, 2009), prefer to join the monitoring committee. The top management team would take longer time in their decision-making process due to gender diversity. Because the board members come from different background and experiences (Sarfaraz, 2017; Berger, et al. 2012), it is also possible that they will face a complicated communication process.

There is a study other than studies about board gender diversity and firm performance that examines the relationship between firm merger and acquisition and board gender diversity.) Female directors are less likely to participate in merger and acquisition according to Levi, Li, and Zhang (2014) and if they do, then due to being less overconfident than male directors, female directors are more likely to pay a lower acquisition premium. In addition to this, several behaviour differences between female CFOs and male CFOs have been identified by Huang and Kisgen (2013). Firms are less likely to engage in acquisition and are not inclined to issue debt with female CFOs. As compared to the acquisitions made by male CFOs, the acquisitions made by female CFOs tend to offer higher returns. Therefore men have greater incentives to choose risky investment than women because men are overconfident than women is the conclusion of the study.

Male investors are found to be overconfident than female, where men trade more excessively than women showed Barber and Odean (2001). Holding riskier investment portfolio is men's tendency. Women are revealed to be risk averse as compared to men in handling their mutual fund investment (Dwyer, et al. 2002) is revealed by using data from a national survey of nearly 2000 mutual funds investors. Bliss and Potter (2002) in contrast to this find that women fund manager hold portfolios with slightly more risk than men. The gender diversity within the R\&D teams and its impact on radicalness of innovation are studied by Díaz-García, González-Moreno, and Sáez-Martínez (2013). Gender diversity is found positively related to radical innovation in the results. The change of male CEO to female CEO, however, may lead to a decrease in several measures of risk-taking (Elsaid and Ursel, 2011) like R\&D expenditure and firm leverage.

Three factors related to gender differences between men and women that is risk preferences, social preferences and reaction to competition are listed by Croson and Gneezy (2009). It is argued on the bases of study that women tend to be more risk-averse than men, more sensitive to social cue than men, and lastly to be less competitive than men. They are emotional and less overconfident than men and is explicit in the differences of risk-taking behaviour. Men tend to take risky investment (Dwyer, et al. 2002). Women are more cautious, less aggressive and easier to persuade rather than men stated Powell and Ansic (1997)

\section{Hypothesis Development}

Risk-taking would be affected by behaviour and would even lead to any possible outcomes states Byrness, Miller and Schaefer, (1999). Women tend to be more risk-averse as compared to men both in the psychology and economics literature is argued by several studies like Charness and Gneezy, 2012; Croson 
and Gneezy, (2009) and Powell and Ansic, (1997) as well. There are three important preferences by different gender, according to Croson and Gneezy (2009), which includes risk preferences, reaction to competition and social preferences. Women are found to be more risk averse, sensitivity to social preferences based on the situation and less competitive than men in general from the result obtained by these studies. Byrness, et al. (1999) also supports the finding of women more risk rather than men.

Level of confidence is another characteristic that explains gender differences in risk attitudes. In terms of investing skills, Barber and Odean (2001) find men to be overconfident than women. Men are more often trader and are more likely to choose a riskier investment. As a result, in comparison to their female counterparts males not only sell their investment at the wrong time but also experience high cost of trading. Less trade is done by women, they hold an investment strategy and tend to use the buy. Several differences in the behaviour between female and male executives, in addition, is recognized by Huang and Kisgen (2013). Their result shows that firms with male executives are more likely to engage in the acquisition. Men are overconfident than women, thus have greater tendencies to choose risky investments as it is implied. Female directors tend to be wiser in choosing an investment that can mitigate the chances of the firms facing losses in the future in contrast to male directors. Therefore the differences in risk attitudes between gender are argued to be able to explain the variation of risk-taking the behaviour of gender.

The quality of board discussion and the ability of the board to provide effective oversight of the firm's disclosure and reports (Gul, et al. 2011) is argued to be improved. Gender diversity on board could create better understanding and decision making process can also be improved. While in boardrooms women also tend to take their role seriously, which can lead to "more civilized behavior "( (Khan, Baseer, \& Javed, 2017; Singh and Vinnicombe, 2004). Female directors tend to behave differently than male directors. Female directors appear to be tougher monitors and likely to join the monitoring committee, have better attendance at board meetings than male directors Adam and Ferreira, (2009) stated. Faccio, et al. (2016) suggest that as compared to firms run by male CEOs, firms run by female CEOs have lower leverage, less volatile and a higher chance of survival. Based on the theories and empirical evidence the following hypotheses are formulated;

H1: Board gender diversity is negatively related to corporate risk-taking.

$\mathrm{H} 2$ : Male-only board is positively related to corporate risk-taking

\section{Sample Selection}

Jordanian firms that are listed on the Stock Exchange of Jordan are selected as samples, the firm-year observations are from the year 2004 to 2018. 634 non-financial firms, with 6,816 firm-year observations constitute a final sample. Collected from the Datastream database, these firms are categorised into ten industries based on the industry classification. Because of the differences in the financial structure and regulation (Rajan and Zingalis, 1995), sample excluded financial firms. After excluding incomplete and/or missing information final sample is obtained. The data related to board gender diversity, the number of female directors on boards, board size and a number of independent directors are hand-collected from firms annual reports while firms specific data is collected from Datastream.

\section{Variable Specification}

Corporate risk-taking is the dependent variable in the present study. Board gender diversity is the key independent variable in order to examine the hypotheses. The analysis also controls for other determinants that are commonly found to be significant determinants of risk-taking. These variables are further explained as follows.

This study based on based on Boubakri, et al. (2013b), Faccio, et al. (2011) and John, et al. (2008) uses two measures to proxy for corporate risk-taking. Risk 1 refers to the volatility of a firm's return on asset (ROA) 
over three-year overlapping periods. For example, the amount of risk-taking in the year 2000 is measured as the volatility of ROA from the year 1998 to 2000 . The ROA is defined as the ratio of operating profits to total assets. Risk 2 refers to the difference between the maximum and minimum ROA in three years interval.

This study uses two variables to proxy for board gender diversity to measure the effect of board gender diversity (Gender diversity) on corporate risk-taking. To examine Hypothesis 1, Female director ratio is used to, while the second variable Male-only dummy is used to test Hypothesis 2. Female director ratio measures the number of female directors over the total number of directors on a board. For Male-only dummy, it equals to one if all the directors on board are male and zeroes otherwise. One of the main variables is Male-only because usually, males dominate Jordanian public listed firms.

Leverage, firm size, profitability, sale growth, firm age, board size, board independence, tangibility and dummy market as control variables are commonly found to explain corporate risk-taking behaviour. The level of risk of corporate financing choices is measured by Leverage and is measured as total debt to total assets. These firms are exposed to greater risk of uncertainty that would lead to a higher risk of financial distress when firms are highly leveraged. According to Faccio, et al. ( 2011) thus, leverage is found to be positively related to corporate risk-taking.

The natural logarithm of total assets is used to measure the Firm size where the total assets consist of current assets and fixed assets and Firm age is calculated by the natural logarithm of the number of years from the establishment of the firm until to the year of observation. Corporate risk-taking is negatively related to Firm size and firm age.

Younger and/or smaller firms are found to be more risk-seeking than larger and/or established firms (Faccio, et al. 2011; Boubakri, et al. 2013b; John, et al. 2008). To expand their business operations, smaller and/or younger have to take more risk in order.

Firm's return on asset (ROA) is used to measure Profitability. The ratio of earnings before interest and tax (EBIT) to total assets is defined as profitability. Higher risk taking is indicated by higher ROA volatility. It could also reflect poor management ability rather than firm risk-taking behaviour (Faccio, et al. 2011). Therefore it is necessary to control for profitability, in the analysis. The annual growth rate of sales defines Sales growth and is expected to be positively related to corporate risk-taking behaviour.

Tangibility is expected to be positively related to risk-taking, tangible assets are the physical form of fixed assets that can be as collateral against borrowing. With higher tangibility firms have more capacity to take up more investment because tangible assets can be used as collateral.

By the natural logarithm of the total board of director, Board size is calculated. For each firm Board independent is measured by the ratio of a number of independent directors on the board to the total number of directors on the board. Some scholars (Jackling and Johl, 2009; Carter et al. 2010). claim that the presence of independent directors could increase the quality of corporate governance and also influence the firm's outcomes. Both board size and board independent are expected to be negatively related to risktaking. Corporate risk-taking is expected to be positively related with board independent. In regression analysis industries dummies and year dummies are also included.

\section{Research Design}

This study uses two regression models to examine the relationship between board gender diversity and corporate risk-taking. The first model is the Pooled Ordinary Least Square Regression (OLS) and the second is Panel Data Regression. 


\section{Pooled Ordinary Least Square Regression}

This study employs pooled Ordinary Least Square (OLS) regression with robust standard errors clustered by the firm in order to estimate the relationship between board gender diversity and corporate risk-taking. Pooled OLS is used because the data have both time series and cross-sectional observations. However, the data is unbalanced due to some of the firm-year observation is missing. In order to test the formulated hypotheses, the regression equation is written as:

\section{Panel Data Regression}

To provide robust findings, this study also repeats the analysis using panel data regression. Panel data comprises observations on the same cross-sectional units over several time periods. Both fixed effects and random effects are put to test this study. In order to test whether fixed effects or random effects better explains the sample data, this study utilizes the Hausman test.

\section{Correlation}

Table 1shows the correlation matrix between the variables. The univariate test suggests that Female Director Ratio is negatively related with RISK1 and RISK2 at the 1\% significant level. Meanwhile, MaleOnly dummy is significantly positive with RISK1 and RISK2 at the $1 \%$ level. These univariate relationships are consistent with the expectation of this study. Though the correlation table shows that most of the variables are correlated at the conventional levels, the coefficients are generally less than 0.4. Therefore, no multicollinearity problem is observed.

The variance inflation factor (VIF) of 2.91, also suggest that the predictor variables are moderately correlated. A VIF value less than 10 further confirms that there is not serious multicollinearity problem between the variables.

Table 1 Correlation Matrix

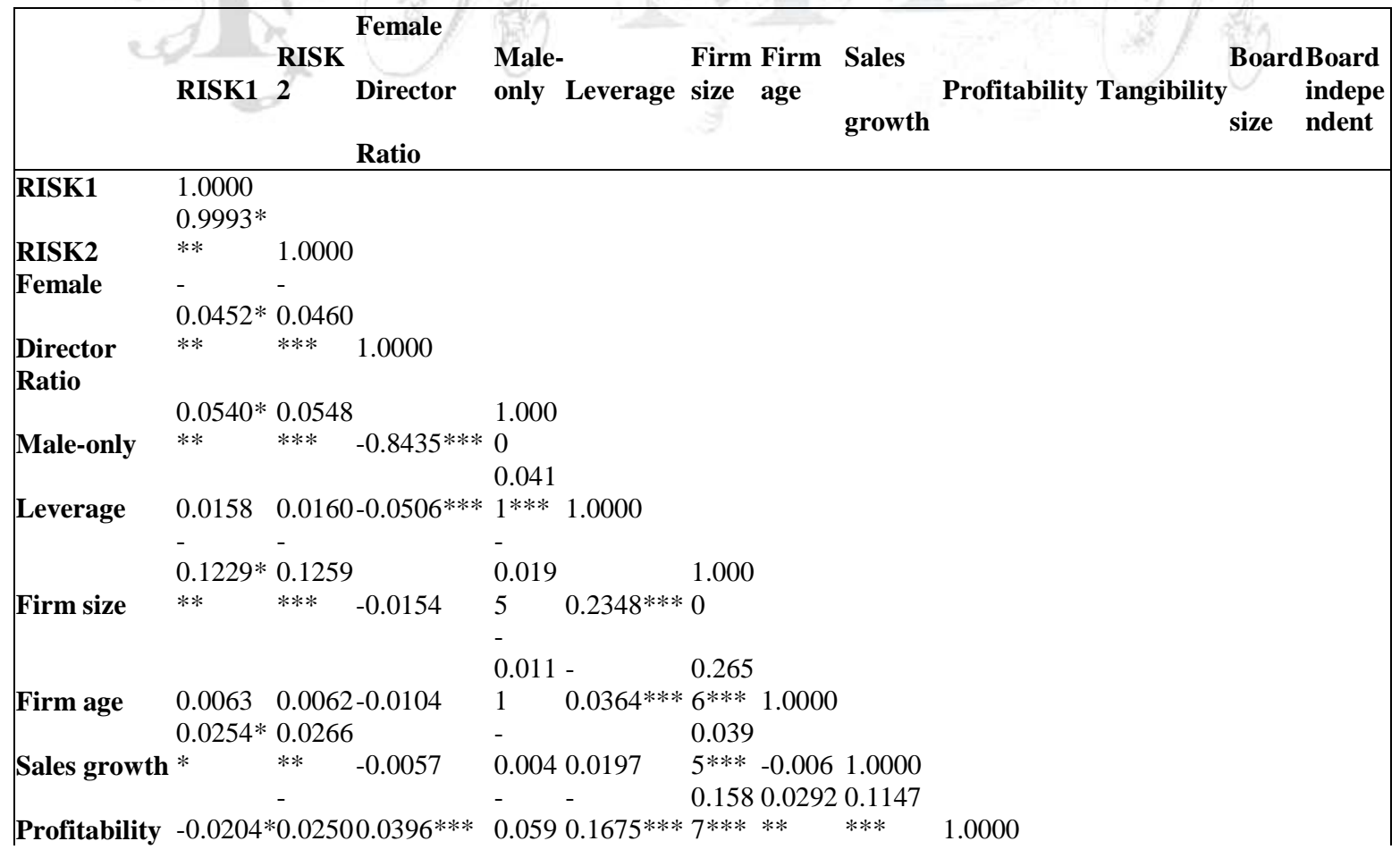




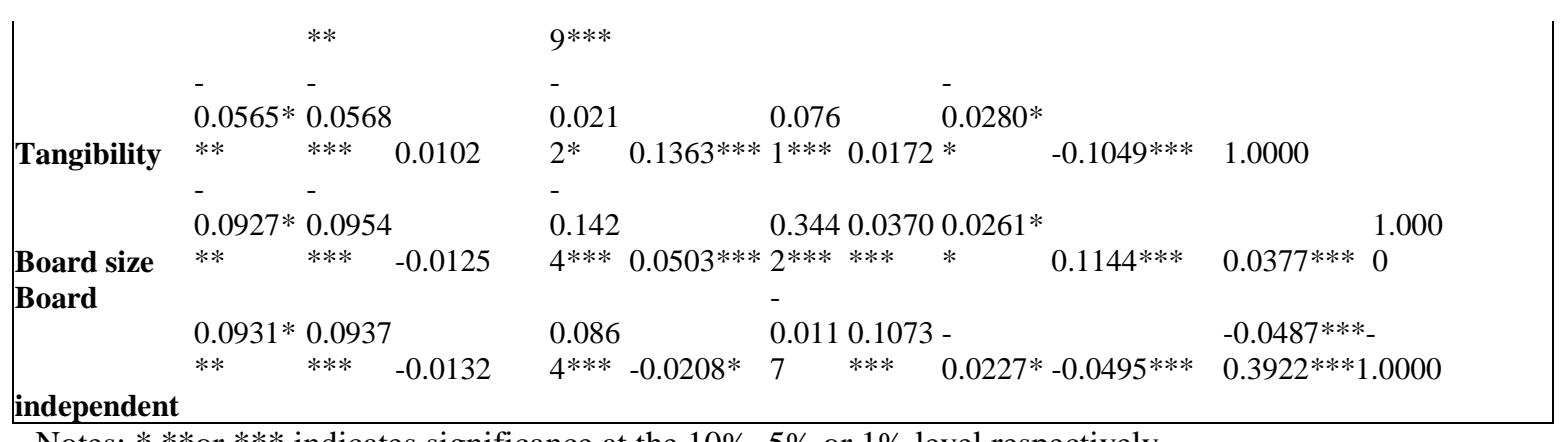

Notes: $* * *$ or $* * *$ indicates significance at the $10 \%, 5 \%$ or $1 \%$ level respectively

\section{Pooled Ordinary Least Square Regression (OLS)}

Table 2 reports the estimates of pooled OLS regression with robust standard errors clustered by firms. Models 1 until 4 in Panel A are designed to examine Hypothesis 1, where the ratio of female directors on boards is used to proxy for gender diversity. Models 1 and 2 do not control for industry and year dummies, but the industry and year dummies are controlled in Models 3 and 4. Female Director Ratio is negatively related to corporate risk-taking. The coefficients are consistently significant at the $5 \%$ level for both measures of risk-taking (RISK1 and RISK2) in all the four models. Referring to Model 3,.one standard deviation increase in female directors' ratio decreases risk-taking by $11.18 \%$ (from $4.30 \%$ to $3.82 \%$ ). ${ }^{1}$ When risk-taking is measured by RISK2 based on Model 4, one standard deviation increase in the female directors ratio, the risk-taking decreases by $10.85 \%$ (from $8.08 \%$ to $7.2 \%$ ). The reported negative relationship supports Hypothesis 1 . The hypothesis argues that board gender diversity is negatively related to corporate risk-taking. In other words, the presence of women on the boards can mitigate risk-taking among the firms.

Models 1 to 4 are designed to test Hypothesis 2 presented in Panel B of Table 2 Similarly, Models 1, 2 do not control for a year, and industry dummies, but Models 3 and 4 do control for the dummies. In Models 1 to 4, the Male-only variable is positively related to corporate risk-taking. The coefficient is consistently significant at the $5 \%$ level for both measures of risk-taking in all the four models. The positive relationship supports Hypothesis 2.

Firms with male-only directors in the boardrooms have greater incentives to take more risk. The coefficient of Male-only indicates that the male-only boards take $0.93 \%$ (refer Model 3) higher risk than firm run by firms with mixed gender boards. This seems to be a sizeable difference given the average of risk-taking (RISK1) of $4.3 \%$ for the full sample. When risk-taking is measured by RISK 2 (refer Model 4), firms with male-only directors take $1.67 \%$ higher risk than mixed-gender boards, relative to the mean of RISK 2 $(8.00 \%)$.

For the control variables, some of the control variables are consistent with the expectations. Leverage, firm size, and sales growth are consistent with the expectations. The reported coefficients of Leverage, Firm size and Sales growth are in line with the study of Faccio, et al. (2011), where leverage and sales growth are positively related to corporate risk-taking, whereas firm size is negatively related to risk-taking, for both measures of risk-taking.

However, firm age is positively, but tangibility is negatively related to risk-taking, suggesting that older firms and/or firms with lower tangible assets take higher risk. These findings are inconsistent with the expected signs. The reported significant relationships are consistently significant at the conventional levels. Firms' profitability, board size and a number of independent directors do not have a significant relationship with corporate risk-taking. 
Table 2 Pooled OLS Regression Adjusted for Robust Standard Error Cluster by Firms

\begin{tabular}{|c|c|c|c|c|}
\hline & (1) RISK1 & (2) RISK2 & (3) RISK1 & (4) RISK2 \\
\hline \multirow[t]{2}{*}{ Female Director Ratio } & $-0.0460 * *$ & $-0.0843 * *$ & $-0.0437 * *$ & $-0.0797 * *$ \\
\hline & $(-2.3583)$ & $(-2.4049)$ & $(-2.1908)$ & $(-2.2279)$ \\
\hline \multirow[t]{2}{*}{ Leverage } & $0.0388 * * *$ & $0.0699 * * *$ & $0.0364 * * *$ & $0.0655 * * *$ \\
\hline & $(2.8399)$ & $(2.8670)$ & $(2.8266)$ & $(2.8507)$ \\
\hline \multirow[t]{2}{*}{ Firm size } & $-0.0267 * * *$ & $-0.0489 * * *$ & $-0.0309 * * *$ & $-0.0565 * * *$ \\
\hline & $(-2.7300)$ & $(-2.8027)$ & $(-2.7964)$ & $(-2.8684)$ \\
\hline \multirow[t]{2}{*}{ Firm age } & $0.0150 * * *$ & $0.0276 * * *$ & $0.0183 * * *$ & $0.0338 * * *$ \\
\hline & $(2.6803)$ & $(2.6630)$ & $(3.2978)$ & $(3.2678)$ \\
\hline \multirow[t]{2}{*}{ Sales growth } & $0.0065^{* *}$ & $0.0123 * *$ & $0.0071 * *$ & $0.0135^{* *}$ \\
\hline & $(2.1210)$ & $(2.1680)$ & $(2.4226)$ & $(2.4713)$ \\
\hline \multirow[t]{2}{*}{ Profitability } & 0.0117 & 0.0116 & 0.0173 & 0.0214 \\
\hline & $(0.1892)$ & $(0.1045)$ & $(0.2770)$ & $(0.1905)$ \\
\hline \multirow[t]{2}{*}{ Tangibility } & $-0.0267 * *$ & $-0.0485 * *$ & $-0.0266 * *$ & $-0.0484 * *$ \\
\hline & $(-2.0216)$ & $(-2.0217)$ & $(-2.1871)$ & $(-2.1855)$ \\
\hline \multirow[t]{2}{*}{ Board size } & -0.0197 & -0.0388 & -0.0198 & -0.0391 \\
\hline & $(-0.9198)$ & $(-1.0009)$ & $(-0.9535)$ & $(-1.0395)$ \\
\hline \multirow[t]{2}{*}{ Board independent } & 0.0773 & 0.1387 & 0.0871 & 0.1571 \\
\hline & $(1.3452)$ & $(1.3582)$ & (1.5399) & $(1.5615)$ \\
\hline \multirow[t]{2}{*}{ Constant } & $0.1612 * * *$ & $0.3006 * * *$ & $0.2076 * * *$ & $0.3841 * * *$ \\
\hline & $(5.4705)$ & $(5.6474)$ & $(5.2034)$ & $(5.3570)$ \\
\hline Industry dummies & No & No & Yes & Yes \\
\hline Year dummies & No & No & Yes & Yes \\
\hline Observations & 6,816 & 6,816 & 6,816 & 6,816 \\
\hline Adjusted R-squared & 0.0312 & 0.0324 & 0.0358 & 0.0375 \\
\hline
\end{tabular}

Panel A: Mixed-Gender Board

Notes: ***or $* * *$ indicates significance at the $10 \%, 5 \%$ or $1 \%$ level respectively

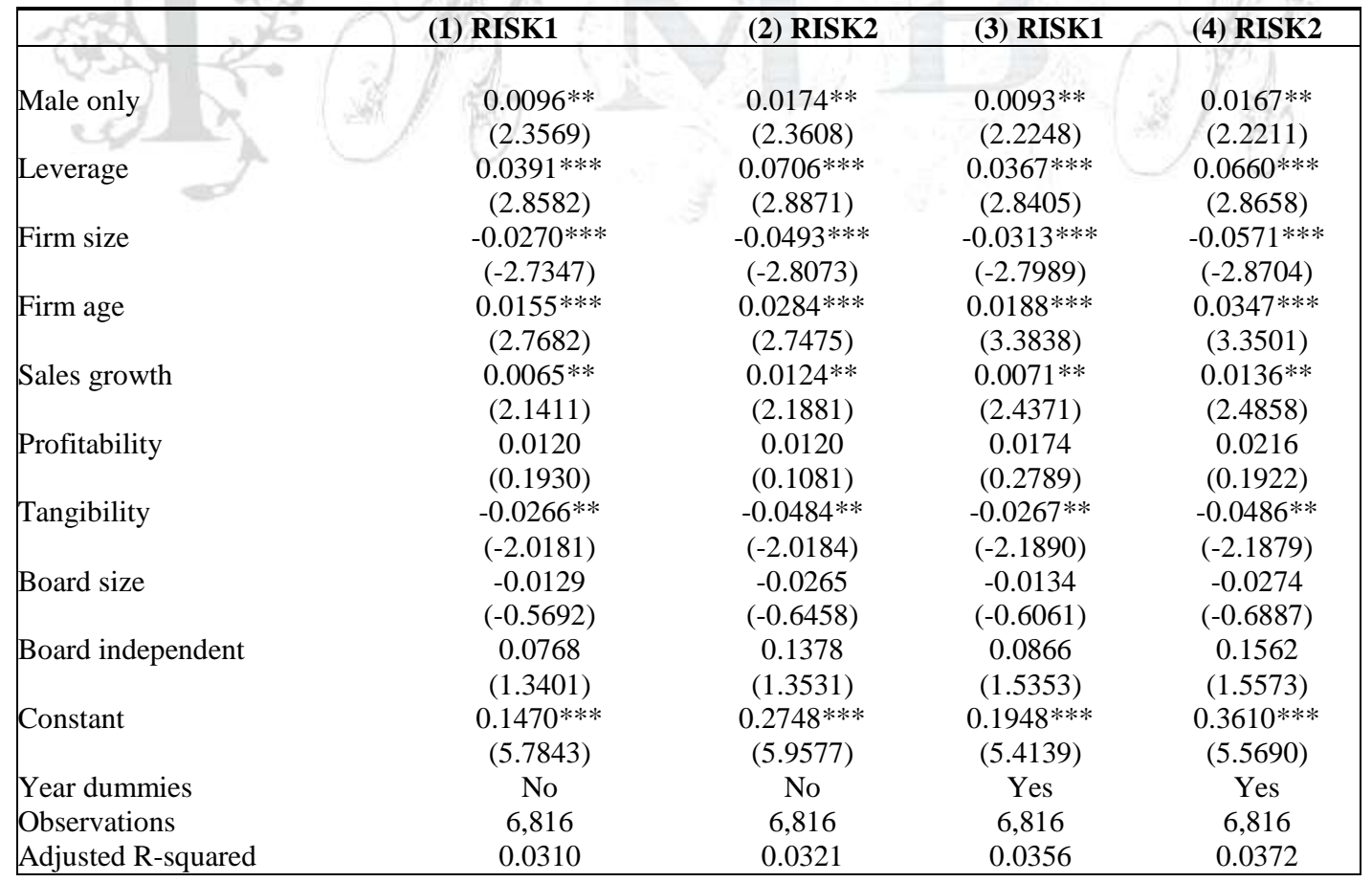

Panel B: Male-only Board

Notes: ${ }^{*} * *$ or $* * *$ indicates significance at the $10 \%, 5 \%$ or $1 \%$ level respectively. 


\section{Panel Data Regression}

To provide robust results, the regression is repeated using fixed effect panel data regression. The regression in Models 1 and 2 reports the estimates for female directors' ratio, while Models 3 and 4 report the estimates for male-only directors. The coefficient of Female Director Ratio shows that the presence of women on the board is negatively related to firms' risk-taking behaviour. The negative coefficient is statistically significant at the $1 \%$ level. For male-only boards, the result reports a positive relationship with corporate risk-taking, significant at the level 1\%. These findings further support Hypotheses 1 and 2 . The estimates of the control variables in Table 3 are qualitatively similar to those reported in Table 2 except board independent that is shown to be positively significant at the $1 \%$ level. This suggests that firms with greater board independence take higher risk, which is inconsistent with the expectation of this study.

Though Hausman test consistently, supports fixed effects over random effects, the results of random effects are also presented in Panel B of Table 3 the results from random effects still provide evidence, supporting Hypotheses 1 and 2. The higher the female directors' ratio, the lower the corporate risk-taking would be. In other words, female directors tend to take less risk as compared to male directors. The results suggest that board gender diversity can mitigate corporate risk-taking and contribute to better decision-making process and corporate governance.

Table 3: Panel Data Regression

\begin{tabular}{|c|c|c|c|c|}
\hline$(32)$ & (1) & (2) & (3) & (4) \\
\hline 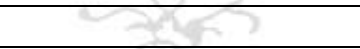 & RISK1 & RISK2 & RISK1 & RISK2 \\
\hline Female Director Ratio & $-0.0435 * * *$ & $-0.0793 * * *$ & & \\
\hline $\mathrm{sec}$ & $(-3.3221)$ & $(-3.3662)$ & & 1 \\
\hline Male only & 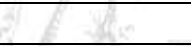 & 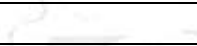 & $0.0091 * * *$ & $0.0164 * * *$ \\
\hline Canso & 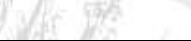 & 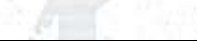 & $(3.0909)$ & $(3.0920)$ \\
\hline Leverage & $0.0365 * * *$ & $0.0657 * * *$ & $0.0368 * * *$ & $0.0662 * * *$ \\
\hline 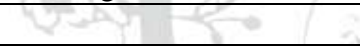 & $(4.1692)$ & $(4.1701)$ & $(4.2026)$ & $(4.2047)$ \\
\hline Firm size & $-0.0308 * * *$ & $-0.0562 * * *$ & $-0.0312 * * *$ & $-0.0568 * * *$ \\
\hline+2 & $(-10.2739)$ & $(-10.4202)$ & $(-10.3664)$ & $(-10.5108)$ \\
\hline Firm age & $0.0185 * * *$ & $0.0342 * * *$ & $0.0190 * * *$ & $0.0351 * * *$ \\
\hline & $(3.4965)$ & $(3.5919)$ & $(3.5887)$ & $(3.6848)$ \\
\hline Sales growth & $0.0072 * * *$ & $0.0138 * * *$ & $0.0072 * * *$ & $0.0138 * * *$ \\
\hline & $(2.6765)$ & $(2.8423)$ & $(2.6874)$ & $(2.8535)$ \\
\hline Profitability & 0.0164 & 0.0195 & 0.0165 & 0.0197 \\
\hline & $(1.0388)$ & $(0.6886)$ & $(1.0450)$ & $(0.6934)$ \\
\hline Tangibility & $-0.0262 * * *$ & $-0.0477 * * *$ & $-0.0263 * * *$ & $-0.0478 * * *$ \\
\hline & $(-3.7062)$ & $(-3.7434)$ & $(-3.7176)$ & $(-3.7561)$ \\
\hline Board size & -0.0186 & -0.0367 & -0.0123 & -0.0253 \\
\hline & $(-1.2385)$ & $(-1.3597)$ & $(-0.8105)$ & $(-0.9299)$ \\
\hline Board independent & $0.0886 * * *$ & $0.1598 * * *$ & $0.0881 * * *$ & $0.1590 * * *$ \\
\hline & $(6.6649)$ & $(6.6793)$ & $(6.6208)$ & $(6.6370)$ \\
\hline Constant & $0.1733 * * *$ & $0.3219 * * *$ & $0.1607 * * *$ & $0.2989 * * *$ \\
\hline & $(9.0364)$ & $(9.3273)$ & $(8.3955)$ & $(8.6817)$ \\
\hline Industry Fixed Effect & Yes & Yes & Yes & Yes \\
\hline Year Fixed Effect & Yes & Yes & Yes & Yes \\
\hline Observations & 6,816 & 6,816 & 6,816 & 6,816 \\
\hline R-squared & 0.0344 & 0.0357 & 0.0342 & 0.0354 \\
\hline
\end{tabular}

Panel A: Fixed effects panel data regression

Notes: $* * *$ or $* * *$ indicates significance at the $10 \%, 5 \%$ or $1 \%$ level respectively 


\begin{tabular}{|c|c|c|c|c|}
\hline & (1) & (2) & (3) & (4) \\
\hline & RISK1 & RISK2 & RISK1 & RISK2 \\
\hline \multirow[t]{2}{*}{ Female Director Ratio } & $-0.0437 * * *$ & $-0.0797 * * *$ & & \\
\hline & $(-3.3733)$ & $(-3.4199)$ & & \\
\hline \multirow[t]{2}{*}{ Male only } & & & $0.0093 * * *$ & $0.0167 * * *$ \\
\hline & & & $(3.1780)$ & (3.1834) \\
\hline \multirow[t]{2}{*}{ Leverage } & $0.0364 * * *$ & $0.0655^{* * *}$ & $0.0367 * * *$ & $0.0660 * * *$ \\
\hline & $(4.2162)$ & $(4.2106)$ & $(4.2451)$ & $(4.2406)$ \\
\hline \multirow[t]{2}{*}{ Firm size } & $-0.0309 * * *$ & $-0.0565 * * *$ & $-0.0313 * * *$ & $-0.0571 * * *$ \\
\hline & $(-10.4478)$ & $(-10.5943)$ & $(-10.5440)$ & $(-10.6888)$ \\
\hline \multirow[t]{2}{*}{ Firm age } & $0.0183 * * *$ & $0.0338 * * *$ & $0.0188 * * *$ & $0.0347 * * *$ \\
\hline & $(3.5077)$ & $(3.5997)$ & $(3.6032)$ & $(3.6960)$ \\
\hline \multirow[t]{2}{*}{ Sales growth } & $0.0071 * * *$ & $0.0135 * * *$ & $0.0071 * * *$ & $0.0136 * * *$ \\
\hline & $(2.6887)$ & $(2.8514)$ & $(2.7035)$ & $(2.8665)$ \\
\hline \multirow[t]{2}{*}{ Profitability } & 0.0173 & 0.0214 & 0.0174 & 0.0216 \\
\hline & $(1.1151)$ & $(0.7659)$ & $(1.1239)$ & $(0.7734)$ \\
\hline \multirow[t]{2}{*}{ Tangibility } & $-0.0266 * * *$ & $-0.0484 * * *$ & $-0.0267 * * *$ & $-0.0486 * * *$ \\
\hline & $(-3.8065)$ & $(-3.8518)$ & $(-3.8150)$ & $(-3.8615)$ \\
\hline Board size & -0.0198 & -0.0391 & -0.0134 & -0.0274 \\
\hline 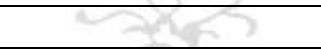 & $(-1.3388)$ & $(-1.4663)$ & $(-0.8950)$ & $(-1.0203)$ \\
\hline Board independent & $0.0871 * * *$ & $0.1571 * * *$ & $0.0866 * * *$ & $0.1562 * * *$ \\
\hline 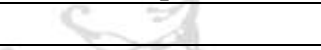 & $(6.6231)$ & $(6.6361)$ & $(6.5782)$ & $(6.5928)$ \\
\hline Constant & $0.2076^{* * * *}$ & $0.3841 * * *$ & $0.1948 * * *$ & $0.3610 * * *$ \\
\hline $8+2$ & $(9.2183)$ & $(9.4796)$ & $(8.6575)$ & $(8.9142)$ \\
\hline Industry effect & Yes & Yes & Yes & Yes \\
\hline Year Effect & Yes & Yes & Yes & Yes \\
\hline Observations & 6,816 & 6,816 & 6,816 & 6,816 \\
\hline
\end{tabular}

Panel B: Random Effects Panel Data Regression

Notes: $* * *$ or $* * *$ indicates significance at the $10 \%, 5 \%$ or $1 \%$ level respectively.

\section{Discussion}

The empirical evidence on the relationship between board gender diversity and corporate risk-taking among Jordanian public listed companies is provided by this study. In the area of corporate governance in recent years, board gender diversity is getting a lot of attention. In the developing markets, however, studies on board gender diversity and corporate risk-taking are still limited specifically. Main objectives of this study examined whether the participation of female directors can mitigate corporate risk-taking is the main objective of this study.

This study by utilizing pooled OLS and panel data regression finds that board gender diversity is negatively related to the corporate risk-taking due to different risk preferences between men and women where the presence of women on boards can decrease the level of firm risk-taking. The male-only boards lead to higher level of risk-taking a while, having women on boards can mitigate corporate risk-taking are shown by the results. Men are overconfident and tend to choose risky projects while women are likely to take less risk. The results support Hypothesis 1 and Hypothesis 2. These results are also consistent with existing studies (Albashabsheh, Aisar, Alhroob, Modafar, Irbihat, Belal, Javed, 2018; Faccio, et al. 2016). 


\section{Significant of Study}

To ensure better corporate governance in the future, findings of this study contribute to the regulators in creating and/or revising more beneficial policies to improve the current policies or regulations. The policies, for example, could enhance and encourage more board gender diversity in future among Jordanian firms.

Moreover how female directors can contribute to enhancing corporate governance could be conveyed to the companies. There will be a contribution to the literature on corporate governance also from this result with evidence from the developing market, in which the study on board gender diversity and corporate risktaking are still relatively unexplored in the Jordanian context.

\section{Recommendation for Future Study}

Using other alternative measures, this study can be further extended to proxy for corporate risk-taking such as volatility of stock returns and industry-adjusted standard deviation of return on assets. Endogeneity problem should also be controlled by future studies. From the reported results, this study acknowledges that the adjusted R-squared are very low as reported by the results. Therefore, there is room to further test this relationship with other control variables. Future study can examine the differences in the risk-taking behaviour and the effects of independent female directors on corporate risk-taking behaviour. Moreover, it is recommended that future study could investigate more about board gender diversity and corporate risktaking especially using evidence from developing markets due to the weaker corporate governance.

\section{References}

Adams, R. B., \& Ferreira, D. (2009). Women in the boardroom and their impact ongovernance and performance. Journal of financial economics,94(2), 291-309.

Albashabsheh, Aisar, Alhroob, Modafar, Irbihat, Belal, Javed, S. (2018). Impact of Accounting Information System In Reducing. International Journal of Research Granthaalayah, 6(July), 210-215. https://doi.org/10.5281/zenodo.1336672

Banoo, S. (2015, September). All on board. Accounting and Business, 60-61. Retrieved http://www.accaglobal.com/content/dam/ACCA_Global/Members/AB/2015/September/AB\%20MY\% 20Sept\%202015.pdf

Barber, B. M., \& Odean, T. (2001). Boys will be boys: Gender, overconfidence, and common stock investment. Quarterly Journal of Economics, 261-292.

Berger, A. N., Kick, T., \& Schaeck, K. (2014). Executive board composition and bank risk taking. Journal of Corporate Finance, 28, 48-65.

Bilimoria, D. (2000). Building the business case for women corporate directors. In Women on corporate boards of directors (pp. 25-40). Springer Netherlands.

Bliss, R. T., \& Potter, M. E. (2002). Mutual fund managers: does gender matter?. The Journal of Business and Economic Studies, 8(1), 1.

Boubakri, N., Cosset, J. C., \& Saffar, W. (2013a). The role of state and foreign owners in corporate risktaking: Evidence from privatization. Journal of Financial Economics, 108(3), 641-658.

Boubakri, N., Mansi, S. A., \& Saffar, W. (2013b). Political institutions, connectedness, and corporate risktaking. Journal of International Business Studies, 44(3), 195-215.

Byrnes, J. P., Miller, D. C., \& Schafer, W. D. (1999). Gender differences in risk taking: A meta-analysis. Psychological Bulletin, 125(3), 367.

Campbell, K., \& Mínguez-Vera, A. (2008). Gender diversity in the boardroom and firm financial performance. Journal of business ethics, 83(3), 435-451. 
Carter, D. A., D'Souza, F., Simkins, B. J., \& Simpson, W. G. (2010). The gender and ethnic diversity of US boards and board committees and firm financial performance. Corporate Governance: An International Review, 18(5), 396-414.

Carter, D. A., Simkins, B. J., \& Simpson, W. G. (2003). Corporate governance, board diversity, and firm value. Financial review, 38(1), 33-53.

Charness, G., \& Gneezy, U. (2012). Strong evidence for gender differences in risk taking. Journal of Economic Behavior \& Organization, 83(1), 50-58.

Croson, R., \& Gneezy, U. (2009). Gender differences in preferences. Journal of Economic literature, 448474.

Cyert, R. M., \& March, J. G. (1963). A behavioural theory of the firm.Englewood Cliffs, NJ, 2.

De Andres, P., \& Vallelado, E. (2008). Corporate governance in banking: The role of the board of directors. Journal of banking \& finance, 32(12), 2570-2580.

Díaz-García, C., González-Moreno, A., \& Jose Sáez-Martínez, F. (2013). Gender diversity within R\&D teams: Its impact on radicalness of nnovation.Innovation, 15(2), 149-160.

Dwyer, P. D., Gilkeson, J. H., \& List, J. A. (2002). Gender differences in revealed risk taking: evidence from mutual fund investors. Economics Letters, 76(2), 151-158.

Eckel, C. C., \& Grossman, P. J. (2008). Forecasting risk attitudes: An experimental study using actual and forecast gamble choices. Journal of Economic Behavior \& Organization, 68(1), 1-17.

Eisenhardt, K. M. (1989). Agency theory: An assessment and review. Academy of management review, 14(1), 57-74.

Elsaid, E., \& Ursel, N. D. (2011). CEO succession, gender and risk taking.Gender in Management: An International Journal, 26(7), 499-512.

Faccio, M., Marchica, M. T., \& Mura, R. (2011). Large shareholder diversification and corporate risktaking. Review of Financial Studies, 24(11), 3601-3641.

Faccio, M., Marchica, M. T., \& Mura, R. (2016). CEO gender, corporate risk-taking, and the efficiency of capital allocation. Journal of Corporate Finance.

Faccio, M., Masulis, R. W., \& McConnell, J. (2006). Political connections and corporate bailouts. The Journal of Finance, 61(6), 2597-2635.

Fama, E. F., \& Jensen, M. C. (1983). Separation of ownership and control. The Journal of Law \& Economics, 26(2), 301-325.

Gul, F. A., Srinidhi, B., \& Ng, A. C. (2011). Does board gender diversity improve the informativeness of stock prices?. Journal of Accounting and Economics, 51(3), 314-338.

Hillman, A. J., Shropshire, C., \& Cannella, A. A. (2007). Organizational predictors of women on corporate boards. Academy of Management Journal,50(4), 941-952.

Hock Ng, T., Lee Chong, L., \& Ismail, H. (2013). Firm size and risk-taking in Malaysia's insurance industry. The Journal of Risk Finance, 14(4), 378-391.

Huang, J., \& Kisgen, D. J. (2013). Gender and corporate finance: Are male executives overconfident relative to female executives?. Journal of Financial Economics, 108(3), 822-839.

Javed, S. (2018). Does Organisation Behaviour Affect Performance Of Auditing Firms ? 5, 90-98. https://doi.org/10.5281/zenodo.1171842

Jensen, M. C., \& Meckling, W. H. (1976). Theory of the firm: Managerial behaviour, agency costs and ownership structure. Journal of financial economics, 3(4), 305-360.

John, K., Litov, L., \& Yeung, B. (2008). Corporate governance and risk-taking. The Journal of Finance, 63(4), 1679-1728.

Khan, A. A., \& Javed, S. (2017). International Journal of Advanced and Applied Sciences a study of volatility behaviour of S \& P BSE BANKEX return in India : A pragmatic approach using GARCH model, 4(4), 127-132.

Khan, A., \& Javed, S. (2016). Determining Factors Responsible in Shifting Consumption of Mobile Data (2G to 3G), 155(14), 30-33. https://doi.org/10.5120/ijca2016912452

Khan, A., Baseer, S., \& Javed, S. (2017). International Journal of Advanced and Applied Sciences Perception of students on usage of mobile data by K-mean clustering algorithm, 4(2), 17-21. 
Legislative Board Diversity. (2013). Retrieved April 06, 2016, from http://www.catalyst.org/legislativeboard-diversity

Levi, M., Li, K., \& Zhang, F. (2014). Director gender and mergers and acquisitions. Journal of Corporate Finance, 28, 185-200.

Low, D. C., Roberts, H., \& Whiting, R. H. (2015). Board gender diversity and firm performance: Empirical evidence from Hong Kong, South Korea, Malaysia and Singapore. Pacific-Basin Finance Journal, 35, 381-401.

Marimuthu, M., \& Kolandaisamy, I. (2009). Ethnic and gender diversity in boards of directors and their relevance to financial performance of Malaysian companies. Journal of Sustainable Development, 2(3), 139.

MCCG. (2007). Malaysian Code on Corporate Governance. Report on Corporate.

Nguyen, P. (2011). Corporate governance and risk-taking: Evidence from Japanese firms. Pacific-Basin Finance Journal, 19(3), 278-297.

Pfeffer, J., \& Salancik, G. R. (1978). The external control of organizations: A resource dependence approach. NY: Harper and Row Publishers.

Phung, A. (2015, May 8). Malaysian women in boards of public companies behind the target, says Najib. the Sundaily. Retrieved http://www.thesundaily.my/news/1412574

Powell, M., \& Ansic, D. (1997). Gender differences in risk behaviour in financial decision-making: An experimental analysis. Journal of economic psychology, 18(6), 605-628.

Rajan, R. G., \& Zingales, L. (1995). What do we know about capital structure? Some evidence from international data. The Journal of Finance,50(5), 1421-1460.

Robinson, G., \& Dechant, K. (1997). Building a business case for diversity. The Academy of Management Executive, 11(3), 21-31.

Rose, C. (2007). Does female board representation influence firm performance? The Danish evidence. Corporate Governance: An International Review, 15(2), 404.

Sarfaraz, J. (2017). Journal of Internet Banking and Commerce Unified Theory of Acceptance And Use Of Technology (Utaut) Model-Mobile Banking. Journal of Internet Banking and Commerce, 22(3), 1-20. Retrieved from http://www.icommercecentral.com/open-access/unified-theory-of-acceptance-and-useof-technology-utaut-modelmobile-banking.pdf

Shukeri, S. N., Shin, O. W., \& Shaari, M. S. (2012). Does the board of director's characteristics affect firm performance? Evidence from Malaysian public listed companies. International Business Research, 5(9), 120.

Singh, V., \& Vinnicombe, S. (2004). Why so few women directors in top UK boardrooms? Evidence and theoretical explanations. Corporate Governance: An International Review, 12(4), 479-488.

Smith, N., Smith, V., \& Verner, M. (2006). Do women in top management affect firm performance? A panel study of 2,500 Danish firms. International Journal of Productivity and Performance Management, 55(7), 569-593.

Tu, T. T. T., Loi, H. H., \& Yen, T. T. H. (2015). Relationship between Gender Diversity on Boards and Firm's Performance-Case Study about ASEAN Banking Sector. International Journal of Financial Research, 6(2), p150.

Waring, A. (2013). Corporate Risk and Governance: An End to Mismanagement, Tunnel Vision and Quackery. Gower Publishing, Ltd.

Xie, B., Davidson, W. N., \& DaDalt, P. J. (2003). Earnings management and corporate governance: the role of the board and the audit committee. Journal of corporate finance, 9(3), 295-316. 